\title{
Actors Affecting Loan Repayment Performance of Micro and Small Enterprises: Evidence from Somali Region, Ethiopia
}

Yitbarek Kiros ( $\nabla$ ykiros@gmail.com )

JigJiga University

Research

Keywords: Loan Repayment Performance, MSEs, Logistic Regression, Somali Microfinance, Ethiopia

Posted Date: October 27th, 2021

DOl: https://doi.org/10.21203/rs.3.rs-968628/v1

License: (c) (1) This work is licensed under a Creative Commons Attribution 4.0 International License.

Read Full License 


\title{
Actors Affecting Loan Repayment Performance of Micro and Small Enterprises: Evidence from Somali Region, Ethiopia
}

\author{
Yitbarek Kiros \\ ykiros@gmail.com \\ Department of Management \\ College of Business and Economics \\ JigJiga University
}

\begin{abstract}
Viable Micro Finance Institutions (MFIs) that reach large number of poor people who are not served by the formal financial institutions have been a prime element for growth of Ethiopia. To operate successfully MFIs have to make sure that loan they disburse have to be repaid back so as to have financially sustainable and viable operation and contribute its own share in poverty reduction of the country. In light of this, this research study was carried to investigate the factors affecting loan settlement of Micro and Small Enterprises(MSEs) financed by Somali Microfinance institution taking lender characteristics in to consideration. Both primary and secondary data was employed used. The primary data was collected by distributing questionnaire and through interview. A total of 175 Micro and Small Enterprises (MSEs) were selected using purposive sampling technique. The secondary data was acquired from various issues of annual reports of Somali Micro Finance institution and other concerned institutions. Both descriptive analysis and econometric model (binary logistic regression) was employed to analyze the effect of the literature driven variables on loan repayment (dependent variable) by borrowers. The binary logistic regression result revealed that among the variables hypothesized to affect loan repayment period, grace period, and timeliness of loan release have statistically significant effect on loan repayment by the borrowers Whereas loan size have statistically insignificant effect on loan repayment performance by the borrowers.
\end{abstract}

Key words: Loan Repayment Performance, MSEs, Logistic Regression, Somali Microfinance, Ethiopia

\section{Introduction}

Microfinance institutions (MFIs) were established to fill the gap in the financial sector by providing funds to the lower income society. In most developing countries the objective of Microfinance Institutions (MFIs) has been: firstly, reducing the risk of income shocks to help reduce poverty and secondly, raising asset accumulation to encourage private activity (Armendáriz \& Gollier, 2000).

One of the methodologies of MFIs is group lending. In group lending, the group obtains a loan under joint liability, so each member is made responsible for 
repayment of loans of his or her peers. The success of MFIs is because, in group based programs, the function of screening, monitoring and enforcement of repayment are to a large extent transferred from the bank to borrowers. The main argument is that, compared to the physically distant banks, group members can obtain at low cost, information regarding the reputation, indebtedness and wealth of the loan applicant and about his or her effort to ensure the repayment of the loan (Norhaziah \& Mohdnoor, 2010).

It is important to note, however, that group lending may not ensure high repayment rates at all times. When loans are received on the basis of joint liability, the risk of loan default by a particular member is shared by his/her peers. It may also be that borrower's assessment of his or her peer's likelihood of defaulting triggers the borrower's own decision to default. And also groups beyond a certain size may experience increased difficulty of communication and coordination so that both information and monitoring advantage of the group are dilute (Manohar \& Zeller, 1997). And also, the lenders cannot observe the behaviors of their clients whether they are honest and dishonest. They only observe the outcome, either the clients repay or not (Norhaziah \& Mohdnoor, 2010). Hence, loan repayment problem is one of the critical issues of MFIs that cause the failure of MFIs (Norhaziah \& Mohdnoor, 2010).

Many scholars have identified many factors that affect the loan repayment performance of the MSEs (Armendáriz \& Gollier, 2000; Bhatt \& Tang, 2001; Manohar \& Zeller, 1997; Njoku \& Odii, 1999; Norhaziah \& Mohdnoor, 2010). In Ethiopia also a number of researchers (Abraham, 2002,; Berhanu, 1999; Daba, 2004; Guush, 2004; Jemal, 2003; Mengistu, 1997 \& 1999; Micha'el, 1996; Teferi, 2000) have identified a number of factors that affect loan repayment of borrowers. In this juncture it can be understood that loan repayment is affected by certain factors in a specific situation.

Somali Microfinance Institution (SMFI) is the only microfinance institution operating in Somali Regional State of Ethiopia. In 2018 the loan default rate of SMFIs was estimated to be $65 \%$. Hence, the purpose of this research was to examine and test the literature driven variably in affecting loan repayment performance of MSEs financed by SMFIs Furthermore, this is the first research conducted on loan repayment performance of MSEs in Somali Regional State of Ethiopia.

\section{Empirical Literature Review}

In an attempt to empirically analyze the loan repayment determinants in micro enterprises in Madagascar, (Zeller 1996), employed a Tobit model using information obtained at the household, group and community level. The result based on 146 sample groups showed that enterprises with higher levels of social cohesion have a better repayment rate. The rxesult also lead to the conclusion that it is not the 
level of physical and human assets of the enterprises but the degree of variance of risky assets among members that contributes to better loan repayment. The result therefore indicated that heterogeneity in asset holdings among members and related intra group diversification in on and off farm enterprises, enables members to pool risks so as to better secure repayment of the loan. Furthermore, gains in the repayment rate due to risk pooling diminish at the margin because of increased costs of coordination, monitoring, and moral hazard that come with greater heterogeneity in groups.

Vigano (1993) in his study about the case of development bank of Burkina Faso employed a credit-scoring model. He found out that being women, married, aged, more business experience, value of assets, timeliness of loan release, small periodical repayments, project diversification and being a pre-existing depositor are positively related to loan repayment performance. On the other hand, loan in kind, smaller loan than required, long waiting period from application to loan release and availability of other source of credit were found to have negative relation with loan repayment performance.

Kashuliza (1993) used a linear regression model to analyze determinants of loan repayment in small holder agriculture in the southern highlands of Tanzania. His study showed that education, attitude towards repayment, farm income and off-farm income positively affect loan repayment with farm income being significant, while age, household expenditure and household size have negative influence on loan repayment performance with household expenditure being significant

Von Pischke (1991) in his explanation about the cause of poor loan collection performance by formal agricultural lenders in developing countries, attributed to general conditions of low levels of economic development. Farm level causes of loan arrears as cited by him include small farmers' poverty, large farmers' political influence, low returns and lack of profitable innovation in tropical and sub-tropical agriculture, unfamiliarity with modern commercial practice among certain rural societies, cultural factors such as the weakness or absence of moral incentives or small group sanctions for timely repayment, illiteracy, lack of farm planning, insufficient supervision, and low level of formal education achieved by typical borrowers. Problems at the lender side include deficiency in loan administration and lack of market information such as system of credit rating based on repayment performance. In addition, difficulty in enforcing contracts through judicial or administrative law process could be cited as a country level problem constraining lender performance.

Hunt (1996) examined the credit rationing technology of lenders and the repayment behavior of borrowers at a rural financial institution taking a sample of 504. Loan rationing equation and loan repayment equations estimated employing Tobit model using survey data at Guyana Cooperative Agricultural and Industrial Development 
Bank revealed that only $33 \%$ of the criteria utilized identified creditworthy borrowers implying that the screening technology was not efficient and needed to be repaired. The results also indicated that tightening the loan contract terms by reducing the grace period on loans and rejecting applications which had long processing times enhanced the pool of credit worthy borrowers. Female borrowers were also not rationed differently than male borrowers nor were they are worse payers than male borrowers (i.e. the variable sex was insignificant), but wealthy borrowers were bad credit risks as their repayment performance is poor. In general, the study showed that only four out of twelve explanatory variables, which are fishing, males in food crops and livestock, credit experience and sugar cane enhance creditworthiness, while other variables especially grace period, delays, and joint borrowers contribute significantly to the default problem.

A study by Ade (1999) on the determinants of small holder loan repayment performance evidence from Nigerian micro-finance system found out that the proportion of borrowers with secondary education, number of times visited by loan officials and the loan size were the major factors that cause the loan default by the borrower.

Arene (1992) in an attempt to evaluate the credit delivery system of Supervised Agricultural Credit Schemes among small holder farmers in Anambra State of Nigeria with emphasis on loan repayment rate conducted a multiple regression analysis. The result is based on 95 sample farmers showed that timely loan repaying farmers had larger loan size, larger farm size, higher income, higher age, higher number of years in farming experience, shorter distance between home and source of loan, higher level of formal education, larger household size, higher level of adoption of innovations, and lower credit needs than defaulting farmers. The regression analysis showed that size of loan, farm size, income, age, number of years of farming experience, level of formal education and adoption to innovations are significantly and positively related to repayment rate, but distance between home and source of loan, household size, and credit needs account for less.

A study made by Njoku and Odii (1999) on the determinants of loan repayment in Nigeria by employing multiple regression model based on 300 sample beneficiaries indicated that poor loan repayment performance was as result of late release of loan funds, cumbersome loan application and disbursement procedures and emphasis on political considerations in loan approvals. In addition, loan diversion to nonagricultural enterprises as well as low enterprise returns resulting from low adoption rate of improved agricultural technologies contributed to poor loan repayment performance of small holders. Loan volume, years of farming experience, farming as major occupation, years of formal education, household size, loan period, farm size, farm output, value of assets and interest paid on loan were all highly significant determinants of loan default. The coefficients of loan volume, years of 
formal education, household size and interest paid on loan are positive while the coefficients for years of farming experience, loan period, farm size, and farming as major occupation, farm output, and value of assets are negative.

An econometric estimation was conducted by Mengistu (1997) based on survey data, on the determinants of loan repayment performance and efficacy of screening mechanism in urban Ethiopia, taking the case of Awassa and Bahir-Dar towns. The estimation result using binomial Probit model revealed that for Awassa, the number of persons employed and weekly installment repayment period are significantly and positively related with repaying loan in full while loan diversion is significantly and negatively related. In terms of the probability of falling in either of the groups, it is found that there is $53 \%$ probability of repaying loan in full. In the case of BahirDar, loan expectation and number of workers employed have a positive relation with full loan repayment while loan diversion and availability of other sources of credit have a negative impact. The predicted probability of full loan repayment in this case is $78 \%$. He employed 352 sample beneficiaries for the case of Awassa and 409 for Bahir-Dar.

Berhanu (1999) and Teferri (2000) made an attempt employing a binomial probit model on determinants of loan repayment performance of micro enterprises with particular reference to POCSSBO in Addis Ababa and DECSI in Tigray. Birhanu found out that loan diversion, loan size and monthly income were undermining factors while beneficiaries' age, perceived cost of default and suitability of repayment period were enhancing factors of loan repayment. Based on 2348 sample beneficiaries Teferri also came up with the result that education and size of loan are significant determinants in all the three cases (i.e. urban, rural and all sample beneficiaries) their sign being positive and negative respectively. Other variables such as sex, timeliness of loan disbursement and monthly income are positively and significantly related with loan repayment in rural and whole sample beneficiaries while loan diversion is negatively and significantly related with full loan repayment in urban and whole sample beneficiaries.

In another relevant study by Abraham (2002) an investigation on the determinants of repayment status of borrowers with reference to private borrowers around Zeway area who are financed by the Development Bank of Ethiopia (DBE). The estimation result employing Tobit model revealed that having other source of income education, work experience in related economic activity before the loan and engaging on economic activities other than agriculture are enhancing while loan diversion, being male borrower and giving extended loan repayment period are undermining factors of loan recovery performance.

Bekele (2003) employed a logistic regression model to analyze the factors influencing loan repayment performance of small holders in Ethiopia. The authors used data on 309 borrowers of input loans in the Oromia and Amhara Regional 
states and found out that individuals who took larger loans had better repayment performances than those who took smaller loans. Further the results of the study revealed that late disbursement of inputs purchased by the loan funds was an important bottleneck in loan repayment while livestock were found to be important in improving the farmers' repayment performance.

Mengistu (1999) also made an empirical analysis on the determinants of industrial loan repayment in Ethiopia with particular reference to manufacturing firms in Addis Ababa. The regression result employing Tobit model based on 65 manufacturing firms revealed that total investment cost, ratio of value of collateral to total loan amount, the firm's grace period, number of disbursement installments, and time were statistically insignificant, while repayment period and number of supervision are significantly and positively related to loan recovery rate. However, coefficients of loan amount and ratio of pre-operating interest to total loan amount are significant at $10 \%$ and $5 \%$ respectively and negatively related with loan recovery rate. Therefore, from the above empirical studies conducted in Ethiopia one can understand that most of them focused on identifying the determinants factors that affect the loan repayment performance of micro and small enterprises located in other parts of Ethiopia. Too little has been known about this issue in Somali regional State. However, to the best knowledge of the researcher there is no research conducted that focused on investigating the key determinant factors that affect loan repayment performance of the micro and small enterprises finance by Somali Microfinance Institution (SMFI) in the year 2016.

\section{Hypotheses Development}

\section{Grace Period Vs Loan Repayment}

If large grace period is given, the borrower will have sufficient time for implementation of the loan (project) so that the borrower could properly utilize the loan for the intended purpose and this enables the loan (project) to generate adequate income after it starts operation. Therefore, the borrower will not face repayment problem (Abraham, 2002; Hunt, 1996).

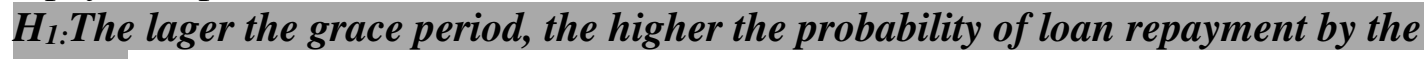
MSEs.

\section{Timeliness of Loan Release Vs Loan Repayment}

If loan is disbursed on time, it is unlikely that it will be diverted to non-intended purposes. The complicated appraisal and approval procedures might delay loan disbursement. Further, this could worsen the prospects of loan repayment by diverting loan to non-intended purpose (Berhanu, 1999; Chirwa, 1997; Daba, 2004; Jemal, 2003; Teferi, 2000; Zeller, 1996).

\section{$\mathrm{H}_{2:}$ The timely the loan is released, the higher the probability of loan repayment by} the MSEs.

\section{Loan Size Vs Loan Repayment}


This is the amount of loan or money the group has borrowed from the micro finance institution. It is argued that smaller amount of loans are insufficient creating cash flow problems to the borrower thus significantly affecting the project (Roslan \& Mohd, 2009). Furthermore, the bigger the loan, the higher is the penalty cost associated with any delinquency or default and this puts more pressure on the borrower to reduce delinquency or default (Manohar \& Zeller, 1997). Therefore, the larger the loan size, the better loan repayment by the group.

$H_{3}$ :The larger the loan size, the higher the probability of loan repayment by the MSES

\section{Repayment Period Vs Loan Repayment}

Repayment period refers to the time period during which the entire loan must be repaid (Roslan \& Mohd, 2009). If it is relaxed, the amount of each installment required to pay will decrease, the debt burden on the borrower will be smaller hence the borrower will not face any difficulty in properly meeting his or her debt obligations (Abraham, 2002). But in this study, the shorter the repayment period, the better will be the loan repayment by the group. This is because; if the repayment period is longer the borrower might use the funds for other purposes hoping to repay the loan from later cash flows (Roslan \& Mohd, 2009; Njoku \& Odii, 1999; Berhanu, 1999; Teferi, 2000).

\section{$H_{4:}$ The shorter the repayment period, the higher the probability of loan repayment} by the MSEs.

\section{Research Method}

\section{Sample Size Determination}

To examine the factors affecting the loan repayment of the MSEs, this study draws on empirical evidence from the 2016 survey covering 175 purposively selected MSEs from Somali regional state of Ethiopia. A structured questionnaire and interview were used to collect first hand data. The data was analyzed using econometric analysis tool, that is, binary logistic regression model was used to test the literature driven hypotheses and to draw conclusions. As per the data obtained from regional bureau of trade and industry, there were 311 Micro and Small Enterprises established and financed by Somali Microfinance Institution in the region. Hence, the sample size (n) is determined to be 175 using the scientific formula given by Yamane (1967), in which $e$ is the level of precision i.e., $e=0.05$ (5\% level of significance). The sample size was determined as follows:

$$
\begin{aligned}
& \mathbf{n}=\frac{N}{1+N(e)^{2}} \\
& \begin{array}{l}
\text { Where: } \mathbf{n}=\text { Sample Size } \\
\mathbf{N}=\text { Population Size, } \\
\boldsymbol{e}=\text { is the level of precision i.e., } e=0.05 \text { (95\% level of significance) }
\end{array}
\end{aligned}
$$




$$
\mathrm{n}=\frac{311}{1+311(0.05)^{2}}=175
$$

\subsection{Econometric Model}

In this study MSEs are assumed to be either defaulting or non-defaulting. Hence the binary choice logistic regression model that assumes dichotomous dependent variable which takes either 1 or 0 value depending on $\mathrm{Y}^{*}$ is used

Let $\mathrm{Y}_{\mathrm{i}}=1$, if the borrower repaid the full amount of the loan within the given maturity period.

$Y_{i}=0$, if the borrower did not repaid the full amount of the loan within the given maturity period.

$$
\begin{aligned}
\text { But } \mathrm{Y}_{\mathrm{i}}=1, \text { if } \mathrm{y}^{*} \text { is }>0 \\
\mathrm{Y}_{\mathrm{i}}=0, \text { if } \mathrm{y}^{*} \text { is } \leq 0
\end{aligned}
$$

Where $y^{*}$ is a latent variable. It is undetected factor which can affect the loan repayment by the borrower. Hence it cannot be measured.

The probability that a borrower will repay the loan $\left(\mathrm{P}_{\mathrm{i}}=1\right)$, is given by:

$$
\mathrm{P}_{\mathrm{i}}\left(\mathrm{Y}_{\mathrm{i}}=1\right)=\frac{1}{1+\mathrm{e}^{-\mathrm{zi}}} \text { or } \frac{\mathrm{e}^{\mathrm{z}}}{1+\mathrm{e}^{\mathrm{z}}}
$$

222If the probability of repaying the loan is given by equation 1 , then the probability of non-repayment of the loan is:

$$
\begin{aligned}
& \mathrm{P}_{\mathrm{i}}\left(\mathrm{Y}_{\mathrm{i}}=0\right) \text { is given by } 1-\mathrm{Pi}=\frac{1}{1+\mathrm{e}^{\mathrm{zi}}} . \text { Hence, it can be re-written as: } \\
& \frac{1-\mathrm{Pi}}{\mathrm{Pi}}=\frac{1+\mathrm{e}^{\mathrm{zi}}}{1+\mathrm{e}^{-\mathrm{z}}}=\mathrm{e}^{\mathrm{zi}}
\end{aligned}
$$

Now, $\frac{\mathrm{Pi}}{1-\mathrm{Pi}}$ is simply the odd ratio- the ratio of the probability that the borrower

\begin{tabular}{|c|c|c|c|}
\hline Variables & Variable & of & Definition of Variable \\
\hline \multicolumn{4}{|c|}{ Dependent Variable } \\
\hline \multirow[t]{2}{*}{ Loan Repayment } & Dummy & $\mathrm{Lr}$ & $\begin{array}{l}0=\text { If loan not fully repaid(Defaulter) } \\
1=\text { If loan fully repaid(Non defaulter) }\end{array}$ \\
\hline & Independ & Taria & \\
\hline Grace period & Dummy & Gp & $\begin{array}{l}0=\text { If grace period is not enough } \\
1=\text { If grace period is enough }\end{array}$ \\
\hline Timeliness of loan release & Dummy & Tlr & $\begin{array}{l}0=\text { If loan is not timely released } \\
1=\text { If loan is timely released }\end{array}$ \\
\hline Loan Size & Continuous & Ls & Measured by the amount of loan taken \\
\hline
\end{tabular}
repays the loan to the probability that the borrower does not repay the loan within the given maturity period. Mathematically, the model is specified as follows:-

$$
\mathbf{L R}=\frac{\mathbf{p i}}{1-\mathrm{pi}}=\boldsymbol{\beta}_{0}+\boldsymbol{\beta}_{1} \mathbf{l s}+\boldsymbol{\beta}_{2} \text { tlr }++\boldsymbol{\beta}_{3} \operatorname{Irp}++\boldsymbol{\beta}_{4} g p+\mathrm{e}_{i}
$$

Where: $\frac{\mathrm{pi}}{1-\mathrm{pi}}=$ Natural logarithm of the odd ratio (logistic model), which is the marginal effect. 


\begin{tabular}{|lll|}
\hline Repayment Period $\quad$ Dummy & $\mathrm{Rp}$ & $\begin{array}{l}0=\text { If repayment period is not enough } \\
1=\text { If repayment period is enough }\end{array}$ \\
\hline
\end{tabular}

\section{Results and Discussion}

According to SMFI the loan given to group owned MSEs is called Urban Package Loan (UPL). It is implemented in collaboration with Regional Bureau of Industry First, the Bureau of Industry screen the applicants as per the below mentioned criterion and provides training to the selected applicants and finally the Bureau transfers the selected applicants to the microfinance institution and up on giving orientation to the applicants, Somali microfinance incaution provide (disburse) the loan to the applicants with the Bureau of Industry as a guarantee. According to the Regional Bureau of Industry, the following are criterion for loan eligibility-:

Clients should be dedicated to use the loan properly and repay it on time.

Clients with clean track record.

Above the age of 18 years and productive.

Have good credit discipline and no mental problems.

Be permanent residents of their respective areas.

Projects financed should be feasible and marketable.

Poor urban and rural people who are able to work and generate income.

* No access to other formal financial institutions.

Therefore, from the above procedure it can be observed that the screening and selection of applicants is completely carried out by the Regional Bureau of Industry. Hence, it can be concluded that the participation of Somali Microfinance institution in the screening and selection of applicants is minimum.

\section{Descriptive Analysis of Dependent Variable}

Regarding loan repayment performance of the MSEs, 58.5\% (102 MSEs) were found to be non-defaulters. According to the respondents, the primary reasons that motivated the borrowers to repay the loan are:

The business was profitable.

It is their obligation to repay the loan.

Fear of losing another loan in the future.

\section{Chart 1: Status of loan repayment}




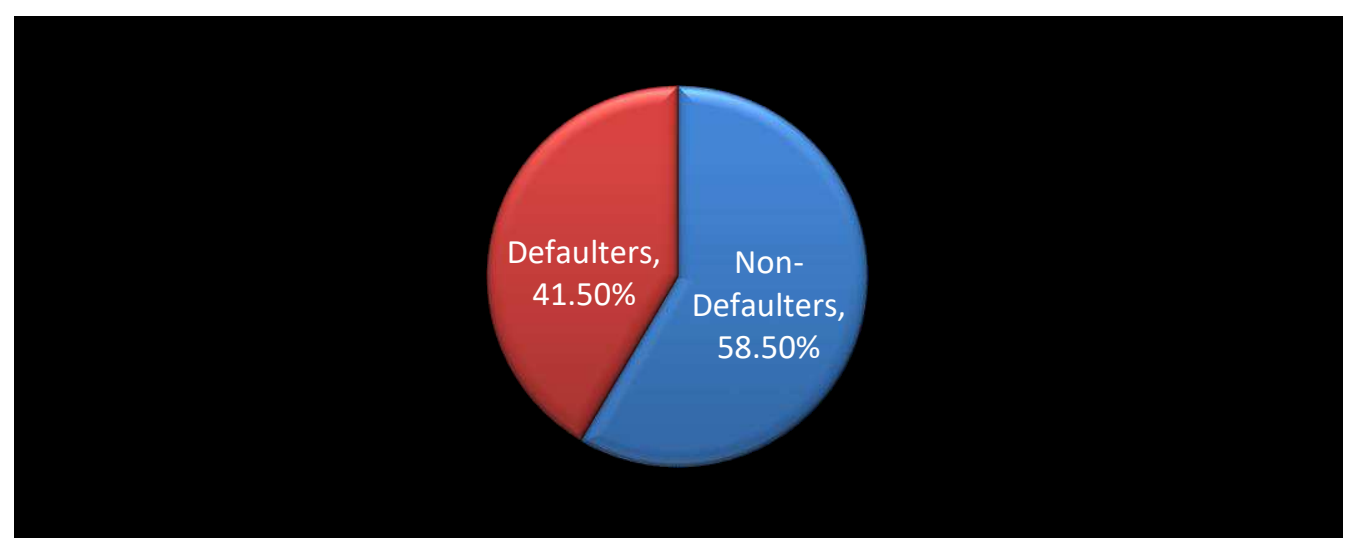

Source: Survey result (2020)

The remaining $45.15 \%$ MSEs were found to be defaulters. According to the respondents the following are the main reasons for their default are:

* Poor Business palm preparation and Study conducted.

Credit sale.

Poor saving habit by members of the enterprise

High consumption habit of members of the business.

Social responsibilities of members, such as money contribution to own clan or tribe.

\section{Determinants of Loan Repayment: Result of Logit Estimation}

\section{Timeliness of Loan Release}

If the loan is released on time it is unlikely that it will be diverted to non-intended purposes. The variable is found to be significant at $10 \%$ level of significance and have positive relationship with loan repayment. The marginal effect of 0.221 implies the probability of loan repayment increases by $22.1 \%$ for those who have received the loan on time as compared to those MSEs who do not received the loan on time. The complicated appraisal and approval procedures could possibly delay loan disbursement. Further this could in turn worsen the prospect of timely loan repayment. The same result was obtained with the findings of Jemal (2003), Zeller (1996), and Teferi (2000). Hence the hypothesis the timely the loan is released, the higher the probability of loan repayment by the MSEs is accepted.

\section{Repayment Period}

The variable repayment period has a positive relationship with loan repayment and is statistically significant at $1 \%$ level of significance. The marginal effect 0.148 implies the probability of loan repayment decreases by $14.8 \%$ for those borrowers who seek larger repayment period as compared to those who do not seek larger repayment period. The possible reason might be, as repayment period gets longer the probability that the borrower might be tempted to spend the income in the early duration or time of the project resulting in potential struggle to make loan payments 
during later periods of the project. The result of this study is also alike with the findings of Njoku and Odii (1999), Roslan and Mhod (2009), Berhanu (1999). But it contradicts with the findings of Abraham (2002). Hence, the hypothesis "the shorter the repayment period, the higher the probability of loan repayment by the MSEs" is accepted.

Table 4: Summary Result of Econometric Model

\begin{tabular}{|llllllll|}
\hline & Odds Ratio & Robust & $\mathrm{z}$ & $\mathrm{P}>|\mathrm{z}|$ & $95 \%$ Conf. Interval] & $\mathrm{dy} / \mathrm{dx}$ \\
\hline Repayment period & 5.494288 & 9.114265 & 9.36 & $0.000^{* * *}$ & $212757.9-1.4208$ & 0.0148471 \\
\hline Grace period & 2.8906 & 6.0406 & 6.11 & $0.000 * * *$ & $4.8308-.0001735$ & -9233988 \\
\hline Loan size & .9454144 & .3877628 & 0.14 & 0.891 & $4231564-2.112241$ & -0000502 \\
\hline $\begin{array}{l}\text { Timeliness of loan } \\
\text { release }\end{array}$ & 3.203125 & 2.224194 & 1.68 & $0.094 *$ & $.821324-12.49204$ & 0.2213501 \\
\hline
\end{tabular}

*** Significant at $1 \%, *$ Significant at $10 \%$

Source: STATA output from survey data (2020).

Table 5: Hypothesis Decision

\begin{tabular}{|lcl|}
\hline Variable & P-value & Decision \\
\hline Loan Size & $0.000 * * *$ & Reject Hypothesis \\
\hline Grace Period & $0.037 * *$ & Reject Hypothesis \\
\hline Repayment Period & $0.000 * * *$ & Accept Hypothesis \\
\hline Timeliness of Loan Release & $0.094 *$ & Accept Hypothesis \\
\hline \multicolumn{2}{|l}{$* * *$ Significant at $1 \%, * *$ Significant at $5 \%, *$ Significant at $10 \%$}
\end{tabular}

\section{Conclusion}

Source: STATA output from survey data (2020).

In developing countries like Ethiopia where unemployment and poverty is very high, micro and small enterprises plays crucial role in creating jobs. Currently, micro and small enterprises are dominating the business in the urban and areas across the world. However, micro and small enterprises face scarcity of capital to develop to medium and large scale enterprises and contribute to the country's economic development. To tackle the problem of capital deficiency of MSEs, credit is a fundamental part for the development of MSEs sector. However, it is important that borrowed funds must be used for intended purposes and for the financial institutions to run profitable business venture so that MSEs can continue to get sustainable source of finance. In microfinance institutions, there are severe problems of loan default which erodes MFIs liquidity position and there by affecting MFIs financial viability and outreach operation. It is with this intention of 
identifying the factors that influence loan repayment performance of MSEs financed by SMFI was the primary motive of this research study.

As per the finding of this research work, of 175 Micro and Small Enterprises (MSEs) 10.2.4 102(58.5\%) MSEs were found to be non-defaulters whereas the remaining $73(41.5 \%)$ MSEs were found to be are defaulters. To identify the most important explanatory variables that affect loan repayment of the MSEs, a research study was conducted using binary logistic regression model. The model reveals that among four explanatory variables which were hypothesized to influence loan repayment, two variables (Repayment Period and Timeliness of loan release) were found to be statistically significant. The remaining two variables, which are, Loan Size and Grace Period, were found to be statistically insignificant. Therefore, Somali Microfinance Institution should revise its policy of loan disbarment and loan collection and above all modernize its loan tracking system using Information Technology (IT) as to ensure timely collection of loans outstanding thereby by sustaining the operation and outreach of the institution.

\section{Declarations}

\section{Availability of data and materials}

All data will be available from the corresponding upon reasonable request.

\section{Competing interests}

The author declared no competing interest.

\section{Funding}

The author confirms no funding of whatsoever has been accepted.

\section{Authors' contributions}

The author has done very aspect of the article as he is the only author of this research article as well as the author has approved the final manuscript of the research.

\section{Acknowledgements}

Not applicable.

\section{Author's Information}

Yitbarek Kiros

JigJiga University

College of Business and Economics

Department of Management

ykiros@gmail.com

JigJiga, Ethiopia

\section{Reference}


Abraham, G. (2002). Loan repayment and its determinants in small scale enterprises financing in Ethiopia the case of private borrowers around zeway area, (Master's Thesis), Addis Ababa University, Ethiopia.

Ade, S. O. (1999). Determinants of small holder loan repayment performance: Evidence from Nigerian micro Finance system. Savings and Development, 1, 95108.

Alemayehu, Y. (2008). The performance of micro finance institutions in Ethiopia: A case of six microfinance institutions, (Master Thesis). Addis Ababa University, Ethiopia.

Arene, C. J. (1992). Loan repayment and technical assistance among small holder maize farmers in Nigeria. African Review of Money, Finance and Banking,

Armendáriz de Aghion, B., \& Gollier, C. (2000). Peer group formation in an adverse selection model. Economic Journal, 110 (01), 632-643.

Bamlaku, A. (2006). Micro financing and poverty reduction in Ethiopia: A paper prepared under the Internship Program of IDRC, Nairobi.

Bekele, T. (2003). Factors influencing loan repayment performance of small holder in Ethiopia, (Masters Thesis), Alemaya University, Ethiopia.

Berhanu, L. (1999). Micro enterprises credit and poverty alleviation in Ethiopia: The case of the project office for the creation of small-scale business opportunities in Addis Ababa, (Masters Thesis), Addis Ababa University, Ethiopia.

Chirwa, E. W. (1997). An econometric analysis of the determinants of agriculture credit payment in Malawi. African Review of Money Finance and Banking, Supplement of the Savings and Development Journal, 1(2), 107-119.

DBE (Development Bank of Ethiopia). (1999). DBE 1999/2000 loan recovery performance report, Addis Ababa, Ethipoia. 
Federal Democratic Republic of Ethiopia. (FDRE). (2011). Micro \& Small Enterprise Development Strategy: Provision framework and methods of implementation. Addis Ababa, Ethiopia.

Federal Micro and Small Enterprise Development Agency. (FeMSEDA). (2016). Micro \& Small Enterprises Sector, Annual Statistical Bulletin. (2010/11-2014/15). Information and Technology Directorate. Addis Ababa, Ethiopia.

Getachew, T., \& Yishak, M. (2005). Integrating financial services into the poverty reduction strategy: The case of Ethiopia paper presented at The East Africa Sub-Regional Workshop, June 28-30, 2006, Dares Salaam, Tanzania.

Hunte, C. K. (1996). Controlling loan default and improving the lending technology in credit institutions. Saving and Development, Quarterly Review, 1:45-59.

International Fund for Agricultural Development. (2001). Ethiopia: Rural financial intermediation program (RUFIP). Appraisal Report Working Paper 1: The microfinance sub-sector.

International Labor Organization. (ILO). (2002). Women and Men in the Informal Economy. A statistical

Jemal, A. (2003). Microfinance and loan repayment performance: Case Study of the Oromia Credit and Savings Share Company (OCSSCO) in Kuyu, (Maters Thesis), Addis Ababa University, Addis Ababa, Ethiopia.

Kashuliza, A. (1993). Loan repayment and its determinants in smallholder agriculture: A case study in the Southern Highlands of Tanzania. East Africa Review, 9(1).

Manohar, S., \& Zeller, M. (1997). Repayment performance in group-based credit programs in Bangladesh: An empirical analysis. World Development, 25(10), 1731-1742. 
Mead, D. C., \& Liedholm, C. (1998). Dynamics of micro and small enterprises in developing countries. Journal of World Development, 26(1), 61-74.

Mengistu, B. (1997). Determinants of micro enterprises loan repayment and efficiency of screening mechanisms in urban Ethiopia: The case of Bahir Dar and Awassa town. Addis Ababa University.

Mengistu, B. (1999). Determinants of industrial loan repayment in Ethiopia: The case of manufacturing firms in Addis Ababa, Proceedings of the 8th Annual Conference on Ethiopian Economy, 117-132.

Micka'el, A. (1996). Micro-finance repayment problems in the informal sector in Addis Ababa. Ethiopian Journal of Business and Development, 1(2).

Ministry of Finance and Economic Development. (MoFED). (2010). Growth and Transformation Plan National Plan Commission. (NPC). ( 2015). The Second Five Year Growth \& Transformation plan

Njoku, J. E., \& Odii, M. A. (1999). Determinants of loan repayment under the special emergency loan scheme (SEALS) in Nigeria: A case study in Imo State. African Review of Money Finance and Banking, 1, 39-51.

Norhaziah, N., \& Mohdnoor, M. (2010). Determinants of repayment performance in microcredit Programs. International Journal of Business and Social Science, 1(2).

Okorie, A. (1986). Major determinants of agricultural small holder loan repayment in a developing economy: Empirical evidence from Ondo State, Nigeria. Savings and Development, 1, 89-98.

Padmanabhan, K. P. (1981). Hedging loan delinquency in rural credit projects: Lessons from Indian experience. Savings and Development journal, 4, 263-270. Picture, International Labor Office, Geneva. Retrieved from http://info: 
Roslan, A. H., \& Mohd, Z. A. (2009). Determinants of micro credit repayment in Malaysia: The case of Agro bank. Journal of Humanity and social sciences, 4(1), 45-52.

Seifu, A. (2002). The demand for micro credit services in the Afar National Regional State. The case of Gewane Woreda. (Master Thesis). Department of RLDS. Strategy: Provision framework and methods of implementation. Addis Ababa, Ethiopia. Technology Directorate. Addis Ababa, Ethiopia.

Teferri, Z. (2000). Micro finance and the poor: The case of Dedebit Credit and Saving Institution (DECSI) in Tigray, (Masters Thesis), Addis Ababa University, Addis Ababa.

Vigano, L. (1993). Credit scoring model for development banks: An African case study. Savings and Development, 17(4), 441-482.

Von Pischke, J. D. (1991). Finance at the frontier: Debt capacity and the role of credit in the private economy. EDI Development Studies. The World Bank, WashingtonD.C.worldbank.org/etools/docs/library/76309/dc2002/proceedin gs/pdfpaper/ odule6ilo3. pd

Yesuf, L. (2010). Performance evaluation of the commercial bank of Ethiopia: Pre and post liberalization, (Master Thesis), Mekelle University, Mekelle.

Zeller, M. (1996). Determinants of repayment performance in credit groups: The role of program design, intra-group risk pooling and social cohesion. Economic Development and Cultural Change, 46(3), 599-621. 